\title{
Effects of Leader Empathy During the Covid-19 Pandemic
}

\author{
Afiah Mukhtar ${ }^{1, *}$, Asmawiyah ${ }^{2}$, Nurjaya ${ }^{3}$, Muhammad Ilyas Thamrin Tahir ${ }^{4}$ \\ ${ }^{1}$ Sekolah Tinggi Ilmu Ekonomi Tri Dharma Nusantara, Indonesia \\ ${ }^{2}$ Sekolah Tinggi Ilmu Ekonomi Tri Dharma Nusantara, Indonesia \\ ${ }^{3}$ Sekolah Tinggi Ilmu Ekonomi Tri Dharma Nusantara, Indonesia \\ ${ }^{4}$ Universitas Negeri Makassar, Indonesia \\ *Corresponding author. Email: afiah.muhtar@stie-tdn.ac.id
}

\begin{abstract}
This study was conducted in a pandemic situation to link leader empathy with the performance of EDC (Electronic Data Chapter) mechanical engineering employees and job satisfaction as an intermediary variable. Using cluster random sampling technique, this research was conducted on 113 employees of technician Electronic Data Chapter (EDC) spread across Indonesia. This study uses primary data (quantitative approach) made in a list of questions to measure respondents' opinions with answer choices on a scale of 1 to 5. help of the SPSS program. Employee performance cannot improve even though the leader's empathy has supported it; This condition is different from the theoretical explanation and the results of previous studies. The problem of the COVID-19 pandemic must be resolved immediately to realize increased performance for employees who do not work from home during the pandemic. To realize employee performance, it must be mediated by a sense of job satisfaction so that job satisfaction factors must be a concern for company leaders.
\end{abstract}

Keywords: Empathy of leaders, Job Satisfaction, Employee Performance

\section{INTRODUCTION}

The Covid-19 virus pandemic has forced leaders to be at the forefront of dealing with various changes that are not as expected. The leader's expertise will appear when faced with unusual situations such as a pandemic requiring leaders to move employees to achieve performance.

Many psychologists from around the world have written about the relationship between empathetic leaders and employee performance [1]. Empathy is an essential implication in social behavior [2]. Empathy is the key to stimulating one's need for achievement. The leader's empathy will raise the perception of subordinates to feel job satisfaction and have an impact on performance [3]. Explains that empathetic leaders are able to create positive relationships with employees' intentions to change for the better. Empathy is needed by everyone in life, including in the work environment [4]. Performance tends to increase with empathy from the leader [5].

The emergence of covid 19 has made shops, mini markets, supermarkets, industries and various companies, both government and non-government to reduce transactions in cash because it is considered that the spread of the covid 19 virus spreads quickly through cash so that Electronic Data Capture (EDC) machines are widely used for transaction tools during the pandemic. This condition makes workers in the field of technicians work extra in pandemic situations, such as making sure the signal is well connected to upgrading new machines.

Previous studies have only examined the performance of employees who do virtual work or work from home (WFH) during a pandemic. However, this research is different from taking samples of employees who continue to work not on a virtual basis because of the type of work as technicians. Generally, in a pandemic situation, employees do virtual work or work from home (WFH) to minimize the interaction of the spread of the covid 19 virus, but this does not apply to employees who work in the field of Electronic Data Capture (EDC) machine technicians, they still have to do their work without being virtual based.

The selection of employee respondents who work on Electronic Data Capture (EDC) machine technicians is a consideration for the writing team for this research because, in a pandemic situation, they are still required to 
improve their performance. Employees are in an unusual situation and are still required to perform optimally in a pandemic. Employees need assistance from leaders who have empathy that can foster employee job satisfaction, which encourages performance. Based on the reasons for selecting the object of research and existing theories, it is interesting to study whether leader empathy affects employee performance during the Covid-19 pandemic if it is supported by job satisfaction as an intervening variable.

\section{LITERATURE REVIEW}

\subsection{Leader Empathy}

Empathy is a response that is formed from cognitive processes due to one's view of understanding others [6]. Empathy is important in leadership behavior because it is related to leader performance [7]. Empathy is a proper understanding of humans [8].

Feelings of empathy require self-awareness in perceiving emotions to others to understand what others need [9]. Empathy is a process of incorporating self and others that involves perception and incorporation of dialogue [10]. There are four general theories of leadership: 1) trait theory (19th century), 2) behavioral style theory (the early 1960s), 3) situational and contingency theory, 4) functional theory. A good leader is a leader who can be aware of his own behavior and its influence on others, understand the differences between others in characteristics and motivation [11]

\subsection{Job Satisfaction}

Job satisfaction is everything that makes employees feel happy at work. Job satisfaction consists of physical, psychological and environmental factors that give rise to honest statements with the word satisfied with their work.

Job satisfaction is defined as a form of people's attitudes and feelings about their work. Job satisfaction is also defined in the form of a positive attitude of feeling happy about work [13]. Factors that can affect job satisfaction are job seniority, financial compensation, position in the organization [14]

\subsection{Employee Performance}

According to [15] performance results from individual or group work achievements with predetermined goals. Meanwhile, Akbar performance is the optimal effort made by someone to get satisfactory results; If the work is good, it will positively impact workers and the work environment [16]. Performance is an achievement that is obtained from the results of work [17].
The elements used as performance measurements are quality, quantity, accuracy, accuracy and creativity [18]

\subsection{The Relationship Of Leader Empathy To Job Satisfaction And Employee Performance}

The relationship of leaders who empathize with employee performance through job satisfaction has a positive and relevant relationship [19]. The sense of empathy that leaders have can affect employee performance [20]. A good leader is a leader who can be aware of his own behaviour and its influence on others, understand the differences in characteristics and motivation. Empathy arises from the use of psychological terms; the process of empathy is able to control one's behaviour and thoughts. Giving feedback will occur between subordinates and leaders. Subordinates will give negative feedback if they do not get a sense of empathy from the leader.

The empathic nature of a leader will strengthen the extent to which the emotional reactions of subordinates and emotional reactions will help subordinates in solving their problems at work [21]. Leader-member exchange (LMX) theory in 1975 in principle that between leaders and subordinates in developing interactions there is a reciprocal relationship, if the perception of the quality of subordinates is low towards the leader, the subordinates will give a low response to the performance, and vice versa [22] further explained that employees need leaders who empathize with their subordinates [23]. When a leader shows empathy to employees, it can elicit positive emotions that result even from receiving negative feedback; it is these emotions that trigger performance [24]. Leaders who have good ethical values will be motivated to help, support and develop employee abilities, but a good leader is he who is able to understand his needs and feelings first. The expected leaders are those who are able to listen to the problems of their subordinates; Leaders who have ethical values will tend to show empathy to their subordinates [25]

\subsection{Hypothesis}

1) Leader empathy has a significant positive effect on job satisfaction

2) Leader empathy has a significant positive effect on employee performance

3) Leader empathy has a significant positive effect on employee performance through job satisfaction 


\section{RESEARCH METHODS AND MATERIAL}

This study uses primary data (quantitative approach) made in a list of questions to measure respondents' opinions with answer choices on a scale of 1 to 5. SPSS program assistance. The questionnaire was made in a google form by testing three variables, namely leader empathy, performance and job satisfaction as intervening variables. Questionnaires were distributed to the EDC mechanical engineering worker group via the WhatsApp application.

The population in this study is Electronic Data Capture (EDC) mechanical technician workers who come from the islands of Sulawesi, Sumatra, Java and Bali because they are classified as cities with reasonably good economic growth in Indonesia.

Using cluster random sampling technique, this research was conducted on 113 employees of technician Electronic Data Chapter (EDC). The selection of employee respondents who work as mechanical technicians (EDC) is a consideration because workers are required to perform optimally in the conditions of the covid-19 pandemic due to the high use of transactions with EDC machines compared to cash payment methods during the pandemic.

\section{RESUlTS AND DISCUSSION}

\subsection{Statistics Results}

\subsubsection{Model 1's coefficient path test}

Based on the model regression output 1, At the table of the coefficents, variable $\mathrm{x}$ or leader empathy obtained a significance of 0.000 smaller than 0.05 . This result suggests that the regression of model 1 , the variable of leader empathy, significantly impacts job satisfaction.

Based on Table II obtained 0.423 for the value of R2. This shows that the contribution of the leader's empathy to job satisfaction is $42.3 \%$, while the remaining 57.7 is the contribution of other variables not tested in the study.

While value $\mathrm{e} 1$ can be found in the formula e $1=$ $\sqrt{(1-0,423)}=0,760$ thus obtained a diagram of one structural model path.

Figure 1. Coefficient Path Model 1

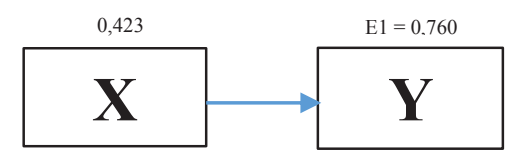

Table 1. Model 1's Coefficient Path Test

\begin{tabular}{|c|c|c|c|c|c|}
\hline Model & \multicolumn{2}{|c|}{$\begin{array}{c}\text { Unstandardized } \\
\text { Coefficients }\end{array}$} & $\begin{array}{c}\text { Standardiz } \\
\text { ed } \\
\text { Coefficien } \\
\text { ts }\end{array}$ & t & Sig. \\
\cline { 2 - 4 } & B & $\begin{array}{c}\text { Std. } \\
\text { Error }\end{array}$ & Beta & & \\
\hline $\begin{array}{c}\text { (Const } \\
\text { ant) }\end{array}$ & 63.547 & 63.886 & .995 & .322 \\
$1 \begin{array}{c}\text { Job } \\
\text { satisfa } \\
\text { ction } \\
\text { (Y) }\end{array}$ & .821 & .167 & .423 & 4.92 & .000 \\
\hline
\end{tabular}

Table 2. Model Summary

\begin{tabular}{|c|c|c|c|c|}
\hline $\begin{array}{c}\mathrm{M} \\
\text { od } \\
\mathrm{el}\end{array}$ & $\mathrm{R}$ & $\mathrm{R}$ Square & $\begin{array}{c}\text { Adjusted R } \\
\text { Square }\end{array}$ & $\begin{array}{c}\text { Std. Error of the } \\
\text { Estimate }\end{array}$ \\
\hline 1 & $\begin{array}{c}.423 \\
\mathrm{a}\end{array}$ & .179 & .172 & 12.940 \\
\hline \multicolumn{3}{|c|}{ a. Predictors: (Constant), Job satisfaction (Y) } \\
\hline
\end{tabular}

\subsubsection{Model 2's coefficient path test}

Whereas el can be found with formula el= $\sqrt{(1-0,813)}=0,902$ Thus obtained a diagram of the line model structure two as follows:

Figure 2. Coefficient Path Model 2

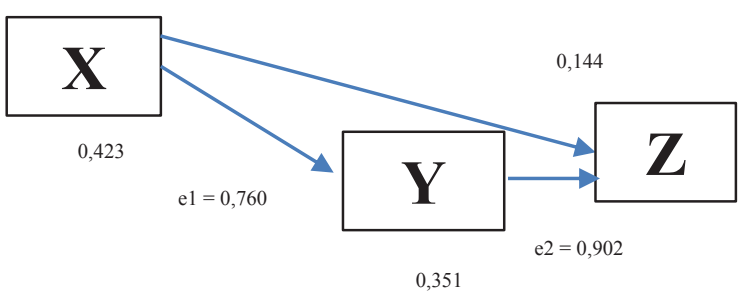

Table 3. Model 2's Path Coefficient Tes

\begin{tabular}{|c|c|c|c|c|c|}
\hline Model & \multicolumn{2}{|c|}{$\begin{array}{c}\text { Unstandardized } \\
\text { Coefficients }\end{array}$} & $\begin{array}{c}\text { Standa } \\
\text { rdized } \\
\text { Coeffi } \\
\text { cients }\end{array}$ & t & Sig. \\
\cline { 2 - 5 } & B & $\begin{array}{c}\text { Std. } \\
\text { Error }\end{array}$ & Beta & & \\
\hline $\begin{array}{c}\text { (Constan } \\
\text { t) } \\
\text { leader's } \\
\text { empathy } \\
\text { (X) } \\
\text { job } \\
\text { satisfacti } \\
\text { on (Y) }\end{array}$ & $\begin{array}{c}260.03 \\
4\end{array}$ & 30.711 & & 8.467 & .000 \\
\hline \multicolumn{7}{|c|}{ a. Dependent Variable: Employee Performance (Z) } \\
\hline
\end{tabular}

Analysis results:

1) The effect of leader empathy $(X)$ on job satisfaction (Y) is positive significant 
2) The effect of leader empathy (X) on employee performance $(Z)$ is positive and not significant

3) The effect of leadership empathy $(\mathrm{X})$ on employee performance $(\mathrm{Z})$ through job satisfaction $(\mathrm{Y})$ is significantly positive

The direct effect $(\mathrm{x})$ Leader's empathy on $(\mathrm{Z})$ job satisfaction is 0.144 or $14.4 \%$. While the indirect effect (x) of leader empathy through (Y) job satisfaction on (Z) employee performance is the multiplication between the beta value of $\mathrm{X}$ against $\mathrm{Y}$ with the value given by $\mathrm{X}$ to $\mathrm{Z}$, which is $0.423 \times 0.351=0.148$. Then the total effect given by $\mathrm{X}$ to $\mathrm{Z}$ is the direct effect plus the indirect effect, namely $0.144+0.148=0.292$. Based on these calculations, the direct influence value is 0.144 , and the indirect effect is 0.148 . The indirect effect value is greater than the immediate influence value; this shows that indirectly $\mathrm{X}$ through $\mathrm{Y}$ significantly impacts $\mathrm{Z}$.

The significance value of the variable $\mathrm{x}$ or leader empathy $=0.000$ is smaller than 0.05 seen in the regression model 1 in the coefficient table. The results of this study conclude that the regression model 1 variable (X) leader empathy has a significant positive effect on employee performance $(Z)$.

\subsection{Discussion}

\subsubsection{Hypothesis 1}

Empathy has many benefits [26]. The leader's humility in understanding the feelings of others will have a positive impact on his subordinates [27]. Humility behavior that combines intrinsic factors and management motives will affect leaders and subordinates [28].

The results of research testing can be interpreted that the leader's empathy can motivate employees to obtain job satisfaction. Empathy is an essential behavior in leadership. Empathy can show a positive relationship with a leader's leadership pattern [29]. Empathy is an essential basic competency that a person has because it is part of the competency problem [30]. When the company provides support, especially from leaders in the organization, employees will respond with pleasant behavior towards their organization [31]. Empathy is the ability to understand the feelings of others. This condition can have a positive impact if the leader has a sense of empathy. This condition can positively impact if the leader has a sense of empathy. Empathy is the ability to respect others, care about employees' lives, and understand other people's problems. subordinates [32].

Empathetic leaders can explain several factors leaders who can build personal relationships with employees and employees who need good personal closeness with subordinates to increase employee morale. Table to motivate to encourage the growth of employee morale so that the leadership can continue to motivate employees, and when employees get motivated, there will be a sense of worker satisfaction. Adaptability in change, an empathetic leader, reflected in the rapid adaptation to various situations, the emergence of the covid 19 virus requires leaders to adapt not only to the conditions of employees, organizations, and situations wisely. Leaders who can adapt to changes who understand policies, company policies provide authority will give a sense of individual job satisfaction to subordinates establish cooperation; for this situation, the leader must be able to create a climate of cooperation, and this is very important because an unfavorable situation makes many changes in working conditions. Therefore, the ability to build a climate of cooperation becomes very important. When a climate of cooperation exists in the organization, subordinates will be satisfied. Trust in subordinates; Due to unfavorable conditions, much work to be done remotely and social restrictions imposed by the government, it takes a leader who believes in subordinates in these working conditions. Believing in subordinates with all their potential, a delegation of authority makes subordinates believe that the company trusts subordinates to develop the company even in a pandemic situation so that subordinates feel happy about it. Making peace with oneself, the pandemic situation encourages leaders to make peace with the pandemic condition, dare to accept forgiveness, and be able to evaluate mistakes. It is undeniable that employees who work in pandemic conditions are very likely to make many mistakes, so empathy from the leadership can drive job satisfaction for employees in the Covid-19 pandemic situation.

\subsubsection{Hypothesis 2}

Anger is a stronger motivator than empathy for conditions of social change in favourable situations [33]. Many factors that can be used for positive behaviour in a social environment are empathy, anger, jealousy, fear, religious fervour, and shame can bring good. There are many reasons why a person cannot empathize with another person due to a lack of emotional reaction. However, when someone has few emotional reactions, it is not that a leader does not care about their subordinates' well-being, but that there are emotions and considerations beyond empathy, and there are many reasons why leaders can empathize with their subordinates [34]. Empathy is seen as a field within cognitive neuroscience; the concept of empathy is very appropriate in the study of social behaviour and its relation to established theories that can understand the behaviour of others because the condition of a leader combines thinking and simulation [35]. Psychological and physical factors influence a person's work. Empathy is a social interaction defined as one's 
ability to understand, sensitivity, awareness, and the ability to understand one's experience. Employee performance is influenced by the empathic response factor from the leader, so several studies of empathy and performance have been conducted extensively [36]. A leader's empathy is an essential factor in influencing subordinates. Empathy attention is considered the driving force for the behaviour of others; at this point in the condition of empathy provided by the leader motivates workers to be able to produce performance [37].

People who have high empathy behaviour will tend to get higher performance [38]. The effect of leader empathy on employee performance is positive, not significant. The results of this study can be interpreted that leadership empathy is not able to encourage increased performance. Generally, in a pandemic situation, employees complete work on a virtual basis but in different conditions with mechanical technician workers (EDC), they must continue to work in the field, so a leader who has a sense of empathy is needed. It is not easy to manage employees to produce performance in a pandemic situation so that it is not only the leader's empathy factor that is needed but many factors that become further studies to produce employee performance in a pandemic situation. Similar to the statement [39] that the virtual work environment conditions are challenging to develop supervision such as information control mechanisms so that to realize what is expected, mutual trust between leaders and subordinates is needed. Many factors that can be used to realize performance are empathy, anger, jealousy, fear, enthusiasm, shame, and so on, which leaders can use as motivation in realizing performance.

\subsubsection{Hypothesis 3}

A happy employee with his job will be able to generate maximum performance because of his sense of job satisfaction [40]. The reflection of a leader influences the perception of its members. Leaders who can take the time to hear problem subordinates, capable of better relationships with subordinates will build job satisfaction for their employees [41]. A good person illustrated in his humility to have good relationships in social conditions, that characteristic is the ability to recognize yourself, the ability to accept new things and be able to give appreciation to others [42]. When leaders have these characteristics can deduce leaders who have good personages. Corporate objectives must not always be supported by high, strong resources, but by a person's empathy ability, they can be used as energy to direct the achievement of the organization [43]. The results of this study are incompatible with [44] that leaders who show empathy for employees can generate positive emotions that result even from negative feedback receiving. It's this emotion that triggers the performance.
Empathetic leadership was needed in the covid-19 pandemics, which proved to be able to drive for increased employee performance is proven in support of great job satisfaction. The effect of leaders' empathy on performance through sustained work satisfaction suggests that leaders' indirect empathy through job satisfaction has a significant impact on performance. Workers' performance would increase if workers gained job satisfaction so that the role of the entering variable became important in the surgical situation. Empathy can contribute to a mutually beneficial exchange relationship. This relationship benefits the subordinate to the empathetic response of the leader [45].

\section{CONCLUSION}

Leader empathy has a positive and significant effect on job satisfaction. Dreamer's empathy has a positive but not significant relationship to performance, but job satisfaction as an intermediary variable can increase worker performance. The Covid-19 problem must be resolved immediately to improve performance for employees who work outside the home / outside the office. Employee performance can increase if mediated by job satisfaction, so that the job satisfaction factor should be a concern for company leaders.

\section{AUTHORS' CONTRIBUTIONS}

The first author compiled, designed the research and wrote the manuscript. The second author analyzed the data, and the third, fourth authors contributed to the revision of the manuscript until all authors agreed on the final result of the manuscript.

\section{ACKNOWLEDGMENTS}

The authors thank the Sekolah Tinggi Ilmu Ekonomi Tri Dharma Nusantara chairman for financial support. The authors also thank the research centre of Sekolah Tinggi Ilmu Ekonomi Tri Dharma Nusantara and all fellow academics who have given many suggestions and comments on this research.

\section{REFERENCES}

[1] Meinecke, A. L., \& Kauffeld, S. (2019). Engaging the Hearts and Minds of Followers: Leader Empathy and Language Style Matching During Appraisal Interviews. Journal of Business and Psychology, 34(4). https://doi.org/10.1007/s10869-018-9554-9

[2] Lamm, C., Rütgen, M., \& Wagner, I. C. (2019). Imaging empathy and prosocial emotions. In Neuroscience Letters (Vol. 693). https://doi.org/10.1016/j.neulet.2017.06.054 
[3] Choi, J. (2006). A Motivational Theory of Charismatic Leadership: Envisioning, Empathy, and Empowerment. Journal of Leadership \& Organizational Studies, 13(1). https://doi.org/10.1177/10717919070130010501

[4] Edmondson, A. C., \& Lei, Z. (2014). Psychological Safety: The History, Renaissance, and Future of an Interpersonal Construct. In Annual Review of Organizational Psychology and Organizational Behavior (Vol. 1). https://doi.org/10.1146/annurevorgpsych-031413-091305

[5] Jiang, W., Wang, L., Chu, Z., \& Zheng, C. (2019). Does leader turnover intention hinder team innovation performance? The roles of leader selfsacrificial behavior and empathic concern. Journal of Business Research, 104. https://doi.org/10.1016/j.jbusres.2019.07.013

[6] Cuff, B. M. P., Brown, S. J., Taylor, L., \& Howat, D. J. (2016). Empathy: A review of the concept. In Emotion Review (Vol. 8, Issue 2). https://doi.org/10.1177/1754073914558466

[7] Sadri, G., Weber, T. J., \& Gentry, W. A. (2011). Empathic emotion and leadership performance: An empirical analysis across 38 countries. Leadership Quarterly, $22(5)$. https://doi.org/10.1016/j.leaqua.2011.07.005

[8] Stuart, W. P., Moore, B., \& Sims, B. M. (2020). Understanding Nurse Perception of Leader Empathy. Nursing Administration Quarterly, 44(1), 78-86.

https://doi.org/10.1097/NAQ.0000000000000396

[9] Hodges, S. D., \& Biswas-Diener, R. (2007). Balancing the empathy expense account: Strategies for regulating empathic response. In Empathy in Mental Illness. https://doi.org/10.1017/CBO9780511543753.022

[10] Cohen, J. (2001). Defining Identification: A Theoretical Look at the Identification of Audiences With Media Characters. Mass Communication and Society, https://doi.org/10.1207/s15327825mcs0403_01

[11] Lawton-Misra, N., \& Pretorius, T. (2021). Leading with heart: academic leadership during the COVID19 crisis. South African Journal of Psychology, 51(2). https://doi.org/10.1177/0081246321992979

[12] Mubarok, A., \& Zein, A. (2019). The Effect of Leadership and Work Motivation on Employee Job Satisfaction at PT Rahman Teknik Perkasa Bekasi. Ubhara Management Scientific Journal, 1(1). https://doi.org/10.31599/jmu.v6i1.493
[13] Loan, L. T. M. (2020). The influence of organizational commitment on employees' job performance: The mediating role of job satisfaction. Management Science Letters, 10(14). https://doi.org/10.5267/j.msl.2020.6.007

[14] Davidescu, A. A. M., Apostu, S. A., Paul, A., \& Casuneanu, I. (2020). Work flexibility, job satisfaction, and job performance among romanian employees-Implications for sustainable human resource management. Sustainability (Switzerland), 12(15). https://doi.org/10.3390/su12156086

[15] Ponto. (2019) The Effect Of Employment Education And Training On Increasing Employees Performance In The North Sulawesi Province Of National And Political Unions.. EMBA Journal: Journal of Economic Research, Management, Business And Accounting 7(3). https://doi.org/10.35794/emba.v7i3.24943.

[16] Akbar, S. (2018). Analysis Of Factors Affecting Employee Performance. Jiaganis (Journal of State Administration and Business Administration),3(1). https://doi.org/10.31227/osf.io/v62c3

[17] Mukhtar, Afiah. The effect of competence and organization culture to work satisfaction and employee performance of Sharia banks in Makassar city. International Journal of Scientific \& Technology Research, 2018, 7.10: 1-6.

[18] Mukhtar, Afiah. Stres Kerja dan Kinerja di Lembaga Perbankan Syariah. Penerbit NEM, 2021

[19] Nurwijayanti, Djabir Hamzah, N. H. (2019). The Influence of Leadership Style And Work Environment On Employee Performance Through Job Satisfaction As An Intervening Variable At Pt. Wedu Merauke Regency. Hasanuddin Journal Of Applied Business And Entrepreneurship Hjabe,2(1).

[20] Kock, N., Mayfield, M., Mayfield, J., Sexton, S., \& De La Garza, L. M. (2019). Empathetic Leadership: How Leader Emotional Support and Understanding Influences Follower Performance. Journal of Leadership and Organizational Studies, 26(2). https://doi.org/10.1177/1548051818806290

[21] Zaki, J., \& Ochsner, K. (2012). The neuroscience of empathy: Progress, pitfalls and promise. In Nature Neuroscience (Vol. 15, Issue 5). https://doi.org/10.1038/nn.3085

[22] Lyubykh, Z. (2016). Perceived disability severity and employee outcomes: The role of leader-member exchange and leader empathy. In ProQuest Dissertations and Theses.

[23] Dewi, N. N., \& Wibowo, R. (2020). The effect of leadership style, organizational culture and 
motivation on employee performance. Management Science Letters, 10(9). https://doi.org/10.5267/j.msl.2020.2.008

[24] Young, S. F., Richard, E. M., Moukarzel, R. G., Steelman, L. A., \& Gentry, W. A. (2017). How empathic concern helps leaders in providing negative feedback: A two-study examination. Journal of Occupational and Organizational Psychology, 90(4). https://doi.org/10.1111/joop.12184

[25] Mahsud, R., Prussia, G., \& Yukl, G. (2010). Leader empathy, ethical leadership, and relations $\square$ oriented behaviors as antecedents of leader member exchange quality. Journal of Managerial Psychology, 25(6). https://doi.org/10.1108/02683941011056932

[26] Ferguson, A. M., Cameron, C. D., \& Inzlicht, M. (2021). When does empathy feel good? In Current Opinion in Behavioral Sciences (Vol. 39). https://doi.org/10.1016/j.cobeha.2021.03.011

[27] Bharanitharan, D. K., Lowe, K. B., Bahmannia, S., Chen, Z. X., \& Cui, L. (2021). Seeing is not believing: Leader humility, hypocrisy, and their impact on followers' behaviors. Leadership Quarterly, 32(2). https://doi.org/10.1016/j.leaqua.2020.101440

[28] Owens, B. P., \& Hekman, D. R. (2012). Modeling how to grow: An inductive examination of humble leader behaviors, contingencies, and outcomes. Academy of Management Journal, 55(4). https://doi.org/10.5465/amj.2010.0441

[29] Kellett, J. B., Humphrey, R. H., \& Sleeth, R. G. (2006). Empathy and the emergence of task and relations leaders. Leadership Quarterly, 17(2). https://doi.org/10.1016/j.leaqua.2005.12.003

[30] Goleman, D. (2003). Working with Emotional Intelligence (Book). BusinessSummaries.Com.

[31] Astuty, I., \& Udin, U. (2020). The Effect of Perceived Organizational Support and Transformational Leadership on Affective Commitment and Employee Performance. Journal of Asian Finance, Economics and Business, 7(10). https://doi.org/10.13106/jafeb.2020.vol7.no10.401

[32] Bloom, P. (2017). Empathy and Its Discontents. In Trends in Cognitive Sciences (Vol. 21, Issue 1). https://doi.org/10.1016/j.tics.2016.11.004

[33] Prinz, J. J. (2012). Is Empathy Necessary for Morality? In Empathy: Philosophical and Psychological Perspectives. https://doi.org/10.1093/acprof:oso/9780199539956. 003.0014
[34] Vachon, D. D., Lynam, D. R., \& Johnson, J. A. (2014). The (Non)relation between empathy and aggression: Surprising results from a meta-analysis. Psychological Bulletin, 140(3). https://doi.org/10.1037/a0035236

[35] Blair, R. J. R. (2005). Responding to the emotions of others: Dissociating forms of empathy through the study of typical and psychiatric populations. Consciousness and Cognition, 14(4). https://doi.org/10.1016/j.concog.2005.06.004

[36] Behm, D. G., \& Carter, T. B. (2021). Empathetic Factors and Influences on Physical Performance: A Topical Review. Frontiers in Psychology, 12. https://doi.org/10.3389/fpsyg.2021.686262

[37] Cornelis, I., Van Hiel, A., De Cremer, D., \& Mayer, D. M. (2013). When leaders choose to be fair: Follower belongingness needs and leader empathy influences leaders' adherence to procedural fairness rules. Journal of Experimental Social Psychology, 49(4). https://doi.org/10.1016/j.jesp.2013.02.016

[38] Yerby, J. (1977). Factors affecting instruction in interpersonal competence. Communication Education, 26(2). https://doi.org/10.1080/03634527709378210

[39] Flavian, C., Guinalíu, M., \& Jordan, P. (2019). Antecedents and consequences of trust on a virtual team leader. European Journal of Management and Business Economics, 28(1) https://doi.org/10.1108/EJMBE-11-2017-0043

[40] Muttaqin, G. F., Taqi, M., \& Arifin, B. (2020). Job Performance During COVID-19 Pandemic: A Study on Indonesian Startup Companies*. Journal of Asian Finance, Economics and Business, 7(12). https://doi.org/10.13106/JAFEB.2020.VOL7.NO12 .1027

[41] Ha, S., Youn, S. J., \& Moon, J. (2020). Emotional Leadership, Leader Legitimacy, and Work Engagement in Retail Distribution Industry. Journal of Distribution $\quad$ Science, 18(7). https://doi.org/10.15722/jds.18.7.202007.27

[42] Owens, B. P., Johnson, M. D., \& Mitchell, T. R. (2013). Expressed humility in organizations: Implications for performance, teams, and leadership. Organization Science, 24(5). https://doi.org/10.1287/orsc.1120.0795

[43] Linneberg, M. S., Trenca, M., \& Noerreklit, H. (2021). Institutional work through empathic engagement. European Management Journal, 39(1). https://doi.org/10.1016/j.emj.2020.08.002

[44] Young, S. F., Richard, E. M., Moukarzel, R. G., Steelman, L. A., \& Gentry, W. A. (2017). How 
empathic concern helps leaders in providing negative feedback: A two-study examination. Journal of Occupational and Organizational Psychology, 90(4). https://doi.org/10.1111/joop.12184

[45] Anaza, N. A., Inyang, A. E., \& Saavedra, J. L. (2018). Empathy and affect in B2B salesperson performance. Journal of Business and Industrial Marketing, 33(1). https://doi.org/10.1108/JBIM-052016-0103 